\title{
Prescriptions of analgesics and anti-inflammatory drugs in municipalities from a Brazilian Southeast state
}

\author{
Alex Júnio Silva da CRUZ(a) \\ Jacqueline Silva SANTOS(a) \\ Edmilson Antônio PEREIRA \\ JÚNIOR(b) (iD \\ Cristina Mariano RUAS(c) \\ Flávio de Freitas MATTOS(d) \\ Lia Silva de CASTILHO(e) (ID \\ Mauro Henrique Nogueira \\ Guimarães ABREU(d) (iD
}

(a) Universidade Federal de Minas Gerais - UFMG, School of Dentistry, Graduate Programme in Dentistry, Belo Horizonte, MG, Brazil.

(b) Universidade Federal de Minas Gerais - UFMG, School of Education, Belo Horizonte, MG, Brazil.

(c) Universidade Federal de Minas Gerais UFMG, School of Pharmacy, Department of Social Pharmacy, Belo Horizonte, MG, Brazil.

(d) Universidade Federal de Minas Gerais UFMG, School of Dentistry, Department of Community and Preventive Dentistry, Belo Horizonte, MG, Brazil.

(e) Universidade Federal de Minas Gerais - UFMG, School of Dentistry, Department of Operative Dentistry, Belo Horizonte, MG, Brazil.

Declaration of Interests: The authors certify that they have no commercial or associative interest that represents a conflict of interest in connection with the manuscript.

\section{Corresponding Author:}

Mauro Henrique Nogueira Guimarães Abreu E-mail: maurohenriqueabreu@gmail.com

ht1ps://doi.org/10.1590/1807-3107bor-2021.vol35.0011
Abstract: The objective of this study was to describe dental prescriptions of non-steroidal anti-inflammatory drugs (NSAID), opioids, and analgesics dispensed by the Brazilian National Health System (BNHS, SUS in Portuguese) of a Southeastern state from January to December 2017, and to analyze their association with socioeconomic and oral health care services' characteristics at municipal level. Data were collected from the Brazilian Integrated Pharmaceutical Care Management System. Medicines were grouped according to the Anatomical Therapeutic Chemical Classification System. The total number of Defined Daily Doses (DDD) and DDD per 1,000 inhabitants (inhab.) per year were presented and compared between groups of municipalities. Data analysis used the Classification and Regression Tree model performed with IBM SPSS 25.0. The total number of NSAID, opioids, and analgesics prescriptions was 70,747 and accounted for 354,221.13 DDD. The most frequently prescribed medicine was ibuprofen ( $\mathrm{n}=24,676 ; 34.88 \%$ ). The number of dental practitioners in the BNHS per 1,000 inhab. $(\mathrm{p}<0.001)$, first dental appointment coverage $(p=0.010)$, oral health teams per 1,000 inhab. $(p=0.022)$, and the proportion of rural population $(p=0.014)$ were variables positively associated with the number of DDD of NSAID per 1,000 inhab. per year. Bolsa Família program coverage per 1,000 inhab. $(p=0.022)$ was negatively associated with NSAID prescription. Regarding analgesics, first dental appointment coverage $(\mathrm{p}=0.002)$ and Bolsa Família program coverage per 1,000 inhab. $(p=0.012)$ were positively associated with DDD per 1,000 inhab. per year. In conclusion, dental prescriptions of analgesics and NSAID in the BNHS were associated with socioeconomic and oral health care services' characteristics.

Keywords: Anti-inflammatory Agents, Non-Steroidal; Analgesics, Opioid; Dentistry; Pharmacoepidemiology.

\section{Introduction}

The prevalence of toothache in Brazilian adults was estimated in $21 \%{ }^{1}$ Submitted: May 21, 2020 Last revision: August 21, 2020
It seems painful conditions are the most common reason for unscheduled visits to the dentist. ${ }^{2}$ The correct management of dental pain includes clinical 
treatment and, when necessary, the prescription of medicines. ${ }^{2,3}$ Nonsteroidal anti-inflammatory drugs (NSAID), opioids, and analgesics are frequently prescribed by dental practitioners. ${ }^{3,4,5}$

Research shows an overall increase in the prescription of medicines to control pain. ${ }^{6,7,8}$ It is recognized that millions of people suffer from untreated pain around the world. ${ }^{9}$ Greater inequalities in the management of pain are found in low and middle-income countries, especially among the vulnerable population. ${ }^{9}$ Some studies reported that poverty, imbalanced income distribution, and health service' characteristics could be associated with health services access and the use of pain relievers. ${ }^{10,11}$

The interest in pharmacoepidemiology studies is growing lately. ${ }^{6}$ However, most of the studies in this field were conducted in developed countries. This could be explained by the limited reliable data on drug consumption available in the Public Health System in some developing countries. ${ }^{12}$ Furthermore, the majority and most recent populational research on analgesics prescriptions by dental practitioners does not evaluate the influence of social health determinants. ${ }^{5-8}$ In this study, we aimed to describe dental prescriptions of NSAID, opioids, and analgesics dispensed by the Brazilian National Health System (BNHS, SUS in Portuguese) of a Southeastern state and to analyze their association with socioeconomic and oral health care services' characteristics at municipal-level from January to December 2017.

\section{Methodology}

\section{Ethical considerations}

The Ethics Committee of the Federal University of Minas Gerais approved this study under the protocol number CAAE- 88465118.8.0000.5149.

\section{Sampling}

This ecological cross-sectional study was based on data retrieved from the Brazilian Integrated Pharmaceutical Care Management System (Sistema Integrado de Gerenciamento da Assistência Farmacêutica-SIGAF) in the state of Minas Gerais from January to December 2017. This state-level system enables pharmaceutical service management and has been used since $2009 .{ }^{13}$ The dataset was accessed after the state's formal permission and under approval of the local ethics committee.

Minas Gerais is one of the 27 states of Brazil. It is located in the southeast region with a total area of 586,521.12 square kilometers $\left(\mathrm{km}^{2}\right)$ and comprises 853 municipalities. ${ }^{14}$ According to the 2010 Demographic Census, the state's population was 19,597,330. (rural population=2,882,114; urban population $=16,715,216) .{ }^{14}$ The state's demographic density was 33.41 inhab. per $\mathrm{km}^{2}{ }^{2}{ }^{14}$ The state's Human Development Index (HDI) is $0.731^{14}$ and GINI index is $0.563 .{ }^{15}$ In June 2017, 1,026,671 families were beneficiaries of the Bolsa Família $(\mathrm{BF})$ program. ${ }^{16}$ $\mathrm{BF}$ program is the national conditional cash transfer program directed to vulnerable families. Its main goals include ensuring the right to food and access to education and health. ${ }^{16}$

All medicines dispensed through dental prescriptions and registered at SIGAF were grouped according to the Anatomical Therapeutic Chemical (ATC) Classification System. ${ }^{17}$ In this system substances are classified according to the physiological system or organ where they act. ${ }^{17,18}$ Drugs belonging to the following ATC Classification System groups were included in the analyzes: M - Musculo-Skeletal System (M01A - Anti-inflammatory and Antirheumatic Products, Non-Steroids) N - Nervous System (N02A Opioids and N02B - Other Analgesics and Antipyretics).

\section{Measurements}

To measure the dispensing process of the studied medicines in each municipality, the Defined Daily Dose (DDD) proposed by WHO was applied. ${ }^{17} \mathrm{DDD}$ is a unit of measurement defined as the average maintenance daily dose for a drug used for its main indication in adults. ${ }^{17}$ Each chemical substance is assigned with a standard DDD that may vary due to the administration route (e.g. oral, parenteral, and rectal). This unit was created to enable the comparison of drug consumption trends across different regions and time. ${ }^{17,18}$

According to the 2019 Guidelines for ATC classification and DDD assignment ${ }^{17}$ and the list of DDD for combined products ${ }^{19}$, the DDD of all chemical substances dispensed by SIGAF were first converted 
into the same unit of mass-milligrams. Then total DDD and DDD per 1,000 inhabitants (inhab.) per year were calculated for each municipality in the state of Minas Gerais. To calculate total DDD, the number of pharmaceutical forms (e.g., number of tablets) of each chemical substance was multiplied by its concentration in milligrams, and the result was divided by the drug-specific DDD. ${ }^{18,20}$ To estimate DDD per 1,000 inhab. per year, the number of DDD was multiplied per 1,000 and then the figure was divided by population. . $^{2,20,21}$ This calculation was independently performed by two of the authors of this paper. When discrepancies were noticed, a pharmacist with more than 10 years of experience in pharmacoepidemiology research was consulted.

The outcome variable in this study was the municipal mean DDD per 1,000 inhab. per year of prescribed NSAID, opioids, and analgesics, individually. Independent variables were organized into two groups of items: a) Municipal data: GINI Index ${ }^{15} \mathrm{HDI},{ }^{22} \mathrm{BF}$ program coverage per 1,000 inhab., ${ }^{16}$ and proportion of rural population. ${ }^{23}$ b) Oral health care services data: dental practitioners in the BNHS per 1,000 inhab., ${ }^{24}$ first dental appointment coverage, ${ }^{24}$ oral health teams per 1,000 inhab. ${ }^{24}$ and proportion of individual clinical procedures ${ }^{24}$ (Table 1).

\section{Statistical analysis}

In the first study stage, descriptive statistics including medicines, number of pharmaceutical forms, and prescribed DDD were performed by calculating frequencies, measures of central tendency, and variability. In the second stage, the Classification and Regression Tree (CART) ${ }^{25}$ was used to identify factors that best discriminated the outcome variable. CART is a decision tree based on the outcome and a set of independent variables. The tree analyzed in this study was the regression type, as it presented a numerical outcome variable.

The great advantage of CART is the intelligibility of the results, as it allows to understand the structure of the classification performed and to present all the

Table 1. Description of the independent variables.

\begin{tabular}{|c|c|c|c|}
\hline Variables & Description & $\begin{array}{l}\text { Reference } \\
\text { year }\end{array}$ & Source \\
\hline \multicolumn{4}{|l|}{ Municipal data } \\
\hline GINI index & $\begin{array}{l}\text { A measure used to calculate the inequalities on income distribution. } \\
\text { Range: } 0 \text { to } 1-1 \text { corresponds to maximal inequality. }\end{array}$ & 2010 & DATASUS \\
\hline $\mathrm{HDI}$ & $\begin{array}{l}\text { A summary measure of three dimensions: income, education, and life expectancy. } \\
\text { Range } 0 \text { to } 1 \text { - the closer to } 1 \text { the greater human development. }\end{array}$ & 2010 & $\begin{array}{l}\text { Atlas of Human } \\
\text { Development in Brazil }\end{array}$ \\
\hline $\begin{array}{l}\text { BF program coverage per } \\
1,000 \text { inhab. }\end{array}$ & $\begin{array}{l}\text { Formula: (number of families benefited by the BF } \\
\text { program X 1,000 inhab.) / population. }\end{array}$ & 2017 & Ministry of Citizenship \\
\hline $\begin{array}{l}\text { Proportion of rural } \\
\text { population }\end{array}$ & $\begin{array}{l}\text { Percentage of the rural resident population by municipality. } \\
\text { Formula: (rural population / total population) X } 100 \text {. }\end{array}$ & 2010 & IBGE \\
\hline \multicolumn{4}{|l|}{ Oral health care services data } \\
\hline $\begin{array}{l}\text { Dental practitioners in the } \\
\text { BNHS per } 1,000 \text { inhab. }\end{array}$ & $\begin{array}{l}\text { The proportion of dental practitioners working in the BNHS per municipality } \\
\text { per 1,000 inhab. } \\
\text { Formula: (number of dental practitioners in the BNHS/ population) X } \\
1.000 \text { inhab. }\end{array}$ & $\begin{array}{l}\text { December } \\
2017\end{array}$ & DATASUS \\
\hline $\begin{array}{l}\text { First dental appointment } \\
\text { coverage }\end{array}$ & $\begin{array}{l}\text { Evaluation of general health conditions and oral clinical examination for } \\
\text { diagnostic purposes and development of a preventive-therapeutic plan. } \\
\text { Formula: (number of first dental appointments / population) X } 100 \text {. }\end{array}$ & 2017 & DATASUS \\
\hline $\begin{array}{l}\text { Oral health teams per } \\
1,000 \text { inhab. }\end{array}$ & $\begin{array}{l}\text { Multidisciplinary work teams composed by a dental practitioner, dental } \\
\text { office assistance, and/ or a dental hygienist. } \\
\text { Formula: number of oral health teams / (population) X } 1.000 \text { inhab. }\end{array}$ & 2017 & DATASUS \\
\hline $\begin{array}{l}\text { Proportion of individual } \\
\text { clinical procedures }\end{array}$ & $\begin{array}{l}\text { Formula: (number of preventive and restorative clinical procedures)/ total } \\
\text { number of dental procedures } X 100 \text {. }\end{array}$ & 2017 & DATASUS \\
\hline
\end{tabular}

BF: Bolsa Família; BNHS: Brazilian National Health System; HDI: Human Development Index; IBGE: Instituto Brasileiro de Geografia e Estatística; inhab: inhabitants. 
subdivisions generated. The logic of this technique lies in the fact that trees are built by subdividing groups into subgroups and so on. ${ }^{25}$ To the successive divisions of the whole dataset was applied Chi-square Automatic Interaction Detection (CHAID). In the development of CART, some criteria were established. First, each node - the name given to each subset resulting from the application of a division rule - had a minimum of 50 observations to proceed with the subdivisions. Second, each terminal node needed a minimum of 30 observations. Third, the model did not consider subdivisions with a probability of significance ( $p$-value) equal to or greater than 0.05 .

\section{Results}

Data on dental prescriptions from 375 cities in the state of Minas Gerais, Brazil, in 2017 were analyzed. Of all patients, 41,847 (59.15\%) were female (data not tabulated). A total of 145,598 dental prescriptions were issued. NSAID, opioids, and analgesics accounted for $49.10 \%$ ( $n=71,499)$. The sum of $752(1.05 \%)$ was excluded from the analysis because the number of pharmaceutical forms and the municipalities where medicines were dispensed were not informed in the database. As a result, 70,747 prescriptions were included in this study: NSAID ( $\mathrm{n}=39,153 ; 55.34 \%)$, analgesics $(n=31,451 ; 44.46 \%)$, and opioids $(n=143$; $0.20 \%$ ). The highest prescription frequencies were observed for ibuprofen ( $n=24,676 ; 34.88 \%$ ), metamizole sodium ( $\mathrm{n}=20,003 ; 28.27 \%)$, and paracetamol ( $\mathrm{n}=11,437 ; 16.17 \%)$. Prescriptions of morphine, tramadol, tramadol combinations, acetylsalicylic acid, and paracetamol combinations were the least frequent, with 1 prescription for each substance (Table 2). The municipal-level socioeconomic and oral health care service' characteristics of the 375 municipalities are presented in Table 3.

The CART analysis for the municipalities that dispensed NSAID (Figure 1) showed the influence of the variable dental practitioners in BNHS per 1,000 inhab. $(p<0.001)$ on the Root Node $([N 0] n=319$;

Table 2. Pain relievers dispensed by dental prescriptions in the Brazilian National Health System in the state of Minas Gerais, 2017.

\begin{tabular}{|c|c|c|c|c|c|}
\hline ATC Code & ATC Name & Frequency & Percentage (\%) & Number of units dispensed & Number of DDD \\
\hline \multicolumn{6}{|c|}{ Non-steroidal anti-inflammatory drugs } \\
\hline M01AB05 & Diclofenac & 4,16 & 5.88 & $72,330.50$ & 36,244 \\
\hline $\mathrm{M} 01 \mathrm{AB} 16$ & Aceclofenac & 41 & 0.06 & 474 & 237 \\
\hline M01AC01 & Piroxicam & 5 & 0.01 & 53 & 53 \\
\hline M01AC06 & Meloxicam & 102 & 0.14 & 1,066 & 1,061 \\
\hline M01AE01 & Ibuprofen & 24,676 & 34.88 & $357,369.50$ & $177,703.33$ \\
\hline M01AE02 & Naproxen & 94 & 0.13 & 1,491 & $1,088.50$ \\
\hline M01AE03 & Ketoprofen & 3 & 0 & 72 & 24 \\
\hline M01AX17 & Nimesulide & 10,072 & 14.24 & $109,092.50$ & $57,588.25$ \\
\hline \multicolumn{6}{|l|}{ Opioids } \\
\hline N02AA01 & Morphine & 1 & 0 & 90 & 9 \\
\hline N02AJ06 & Codeine and paracetamol & 140 & 0.20 & 1,528 & 509.33 \\
\hline N02AJ13 & Tramadol and paracetamol & 1 & 0 & 10 & 2.50 \\
\hline N02AX02 & Tramadol & 1 & 0 & 20 & 3.33 \\
\hline \multicolumn{6}{|l|}{ Analgesics } \\
\hline N02BA01 & Acetylsalicylic acid & 1 & 0 & 30 & 6 \\
\hline N02BB02 & Metamizole sodium & 20,003 & 28.27 & 193,498 & $50,391.17$ \\
\hline N02BB52 & $\begin{array}{c}\text { Metamizole sodium, combinations } \\
\text { excluding psycholeptics }\end{array}$ & 9 & 0.01 & 131 & 15.17 \\
\hline N02BE01 & Paracetamol & 11,437 & 16.17 & $161,846.50$ & $29,283.75$ \\
\hline N02BE51 & $\begin{array}{l}\text { Paracetamol, combinations } \\
\text { excluding psycholeptics }\end{array}$ & 1 & 0 & 12 & 1.80 \\
\hline Total & & 70,747 & 100 & 899,114 & $354,221.13$ \\
\hline
\end{tabular}


Table 3. Socioeconomic and oral health services' characteristics from the 375 municipalities in the state of Minas Gerais, 2017.

\begin{tabular}{lccc}
\hline Variables & Mean & SD & Median \\
\hline GINI index & 0.48 & 0.05 & 0.48 \\
HDI & 0.67 & 0.05 & 0.67 \\
BF program coverage per 1,000 inhab. & 77.48 & 40.14 & 67.71 \\
Proportion of rural population (\%) & 31.78 & 18.85 & 29.46 \\
Dental practitioners in the BNHS per 1,000 inhab. & 0.63 & 0.47 & 0.52 \\
First dental appointment coverage (\%) & 12.57 & 31.13 & 7.67 \\
Oral health teams per 1,000 inhab. & 0.93 & 7.35 & 0.29 \\
Proportion of individual clinical procedures (\%) & 89.34 & 10.99 & 91.13 \\
\hline
\end{tabular}

mean $=91.159$ DDD per 1,000 inhab. per year). The influence of this variable divided the cities into two groups: $\mathrm{N} 1(\mathrm{n}=191$; mean $=66.116)$ and N2 $(\mathrm{n}=128$; mean $=128.529)$. First dental appointment coverage $(\mathrm{p}=0.010)$ subdivided N1 into three subgroups: N3 ( $\mathrm{n}=50$; mean = 32.313), N4 ( $\mathrm{n}=84$; mean = 58.594), and N5 $(\mathrm{n}=57$; mean $=106.853)$. The subdivision of $\mathrm{N} 2$ by BF program coverage per 1,000 inhab. $(\mathrm{p}=0.022)$ originated N6 $(n=80$; mean $=161.209)$ and N7 $(n=48$; mean $=74.062)$. The interaction of number of oral health teams per 1,000 inhab. $(p=0.022)$ and the proportion of rural population $(\mathrm{p}=0.014)$ with $\mathrm{N} 4$ and N6, respectively, produced the terminal nodes $\mathrm{N} 8(\mathrm{n}=52$; mean $=38.159), \mathrm{N} 9(\mathrm{n}=32 ;$ mean $=91.799), \mathrm{N} 10(\mathrm{n}=35$; mean $=92.260)$, and N11 $(n=45$; mean $=214.836)$.

Mean opioid prescription per city per 1,000 inhab. was $5.414 \mathrm{DDD}(\mathrm{SD}=10.759)$. The small number of municipalities that dispensed opioids $(n=20)$ impaired the use of CART. Among the 357 municipalities that dispensed analgesics, first dental appointment coverage $(\mathrm{p}=0.002)$ divided N0 into 2 subgroups: $\mathrm{N} 1(\mathrm{n}=107$; mean $=12.948)$ and $\mathrm{N} 2(\mathrm{n}=250$; mean $=28.557)$. The interaction of the variable BF program coverage per 1,000 inhab. $(p=0.012)$ with the cities in N1 originated the terminal nodes N3 $(n=57$; mean $=6.947)$ and N4 $(n=50$; mean $=19.788)$ (Figure 2).

\section{Discussion}

At city-level, there was an association between social and health care services variables with mean DDD per 1,000 inhab. per year suggesting the influence of social disparities. Based on the reviewed literature, this is the first population-based study developed in Brazil on prescribing patterns of dental practitioners in BNHS.
Together, ibuprofen, metamizole, and paracetamol accounted for the majority of all dental pain prescriptions in the state of Minas Gerais in 2017. In a nationwide survey, paracetamol, metamizole, and ibuprofen were the $7^{\text {th }}, 8^{\text {th }}$ and $12^{\text {th }}$ medicines most used by the Brazilian population. ${ }^{26}$ The high prescription frequency of such chemicals is related to the fact that they are included in the national list of essential medicines. They are also easily available in health units throughout Brazil. ${ }^{27}$ In Australia ${ }^{6,8}$ and Germany, ${ }^{7}$ ibuprofen was also the most prescribed NSAID, probably because of its efficacy in a large range of painful inflammatory conditions and its price. ${ }^{28}$

In 2016, dental prescriptions of NSAID and analgesics in Australia reached 15.60 DDD per 1,000 inhab. per year. ${ }^{8}$ In our study, there were higher prescription means for NSAID. These different findings may be explained by the characteristics and comprehensiveness of public health care systems in both countries, kinds of medicines subsidized by governments (either free of charge or under copayment) and the variety of chemical substances included in each country's list of essential medicines, and national prescribing guidelines and oral health conditions in Brazil. In a previous study, ${ }_{1}^{11}$ DDD of opioids per 1,000 inhab. per year in the state of Minas Gerais was higher than our findings. This discrepancy is related to methodological differences. While in this study we focused on medicines dispensed in BNHS facilities, Lino et al. ${ }^{11}$ assessed medicines dispensed in private drugstores. Opioids are strong analgesics but have significant side effects, thus they should be reserved to manage severe pain only. ${ }^{2}$ Procedures that might induce these levels of pain, such as osseointegrated dental implants, are performed 


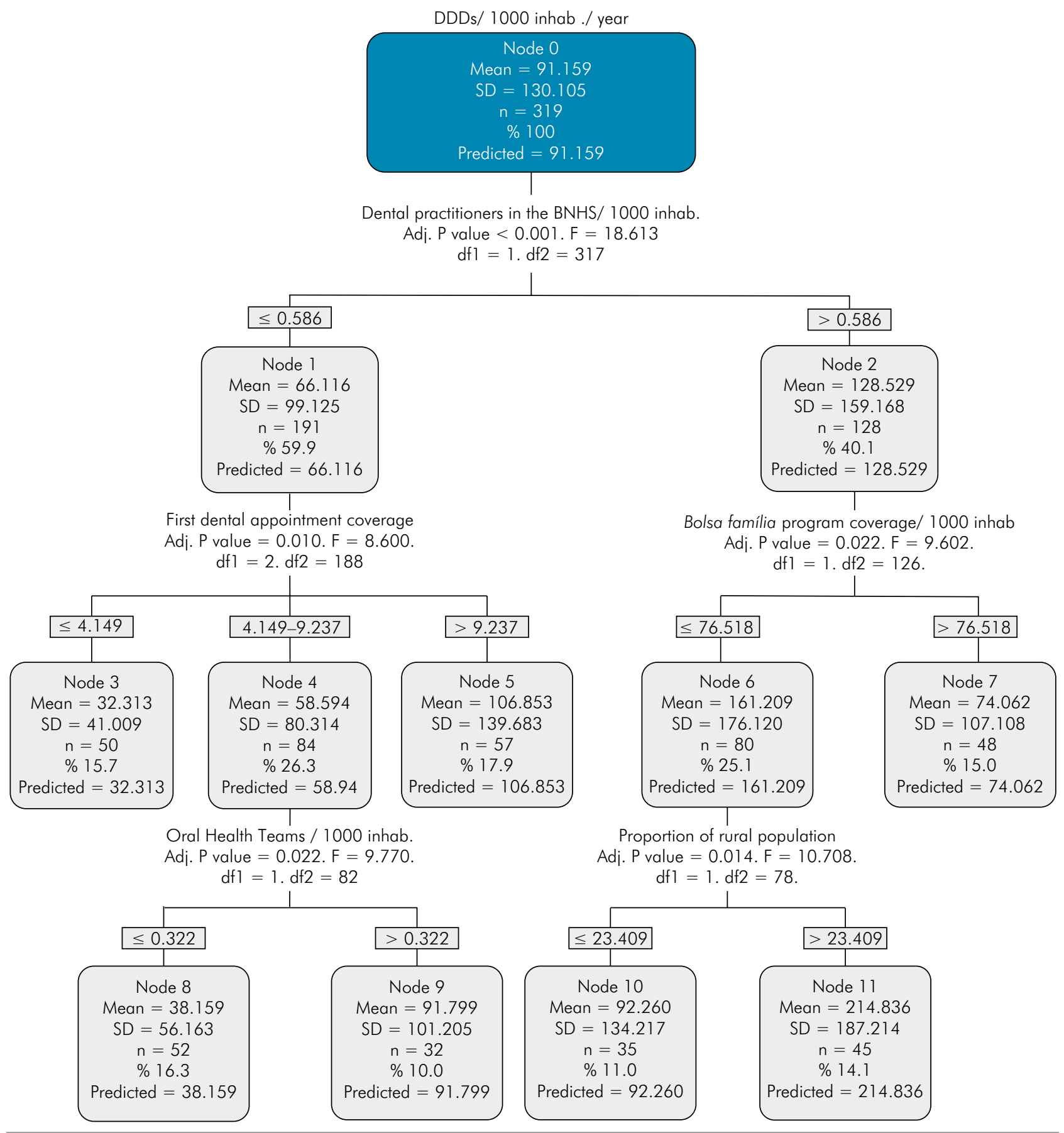

Figure 1. CART analysis for non-steroidal anti-inflammatory drugs.

rarely by the BNHS. ${ }^{29}$ This could be a reason for the low DDD of opioids found in this research.

The process of prescribing, dispensing, and using medicines is closely related to the drugs availability in health services. The greater availability of NSAID and analgesics was positively associated with the number of professionals prescribing them in Brazilian health units. ${ }^{27}$ Although there is not a direct relationship, cities with higher number of prescribing professionals may present higher rates of medicines' availability and, consequently, higher rates of prescription and consumption. Taking into account 


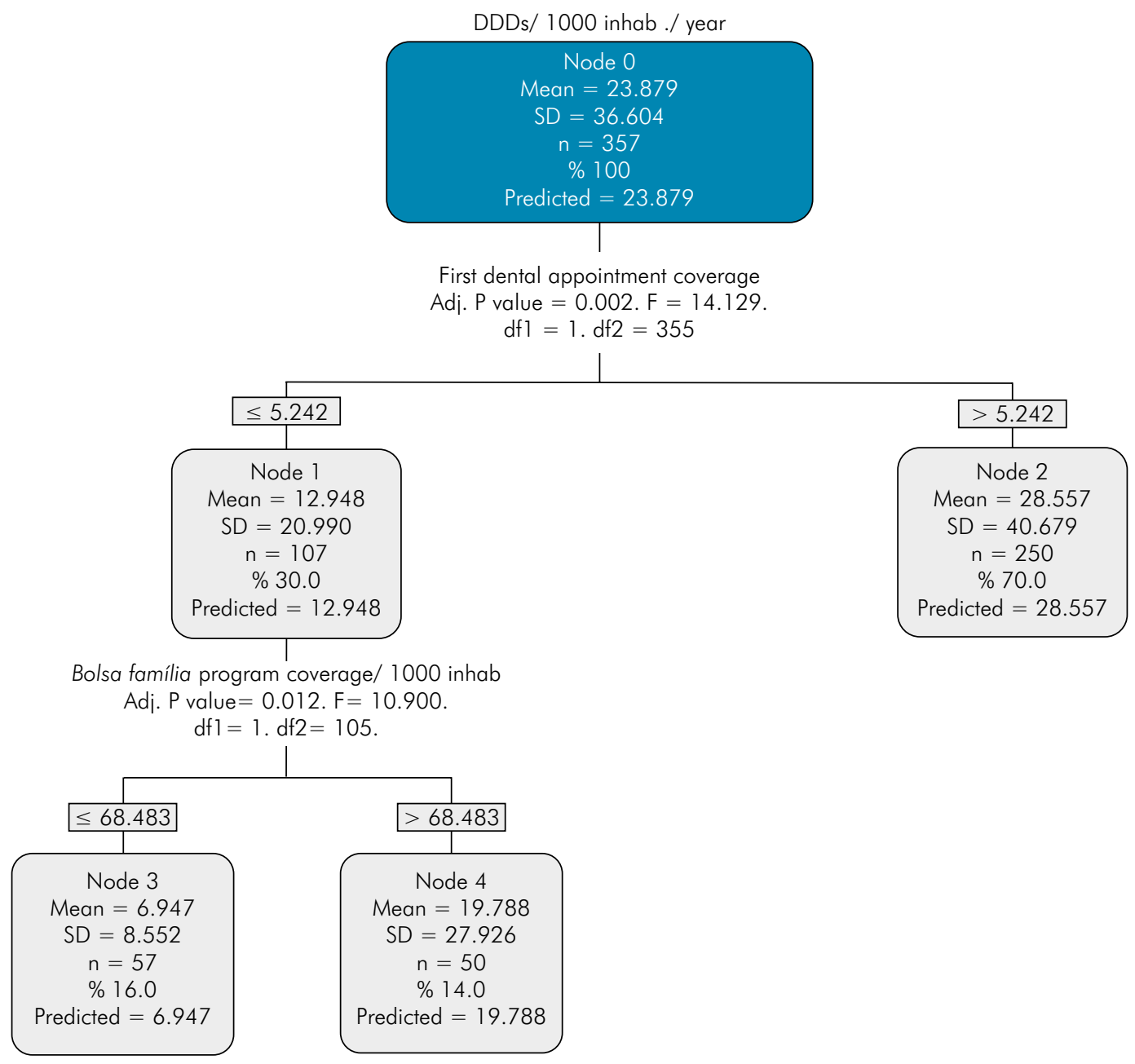

Figure 2. CART analysis for analgesics.

the cross-sectional design of the study, the direction of the relationship is not easy to be determined, and an inverse relationship could exist, i.e. higher rates of medicines' availability could stimulate professionals to prescribe them more often.

The development of oral health policies increased the number of public oral health teams in BNHS in the past decades. ${ }^{30}$ As a consequence, both population access to treatment and the number of oral procedures grew considerably. ${ }^{30}$ The first dental appointment coverage indicates population access to dental services. ${ }^{31}$ It is expected that oral health teams in cities with higher service access rates perform more clinical procedures, including surgeries, endodontics, and dental trauma management. These procedures might induce inflammatory response and pain and the consequent prescription of NSAID and analgesics.

There is a close relationship between inequalities and the burden of oral diseases, poverty, and access to and utilization of oral health care services. ${ }^{32}$ In this matter, conditional cash transfer programs such as $\mathrm{BF}$ tackle social disparities and improve some health outcomes. ${ }^{33,34} \mathrm{BF}$ program directly transfers income to families living in poverty and extreme poverty under compliance with some conditions, such as children's school enrollment and regular health checkups. ${ }^{34} \mathrm{BF}$ was designed for vulnerable people, therefore there is a proxy between the number of its beneficiaries and the proportion of poor people in each city. ${ }^{35}$ In this study, there was a relationship between BF coverage and DDD per 1,000 inhab. for NSAID and 
analgesics. NSAID are known to be more expensive than analgesics. ${ }^{36}$ Health managers in poor cities may tend to purchase more of the latter, and consequently NSAID are less available for prescription by dental practitioners. It may explain the lower NSAID mean DDD and the higher analgesic mean DDD in cities with higher $\mathrm{BF}$ coverage. However, there are very few studies relating $\mathrm{BF}$ program and oral health outcomes in the general population and these results must be interpreted with caution.

A higher NSAID mean DDD per 1,000 inhab. per year was observed in cities with higher proportions of rural population. Evidence suggests there is a link between living in rural areas and poorer access to quality health care services. ${ }^{37}$ Also, dental care is likely to be delayed by people from rural communities. ${ }^{37,38}$ As a consequence, oral diseases are diagnosed in advanced stages and increase the demand for dental extractions and emergency services. The delay in receiving dental care and the search for emergency dental treatment explain higher prescription rates in cities with higher proportion of rural population.
This study has some limitations that should be addressed. The cross-sectional methodology has low analytical power. Data for the analyzed variables were collected from different datasets and reproducibility could not be assessed. Inferences in individual level also could not be achieved. Nevertheless, ecological studies allow the analysis of the impact of contextual variables on the outcome and this approach can be useful, especially to evaluate health care policies.

\section{Conclusions}

Dentists' prescription of NSAID and analgesics were associated with municipal characteristics, such as socioeconomic and organization of oral health care services.

\section{Acknowledgments}

We thank Secretaria de Estado de Saúde for providing access to the database. Mauro Henrique Nogueira Guimaraes de Abreu is fellow of CNPq. We would like also to thank Coordenação de Aperfeiçoamento de Pessoal de Nível Superior (CAPES) (financial number 001).

\section{References}

1. Hafner MB, Zanatta J, Rasera Zotelli VL, Batista MJ, Sousa ML. Perception of toothache in adults from state capitals and interior cities within the Brazilian geographic regions. BMC Oral Health. 2013 Jul;13(35):35. https://doi.org/10.1186/1472-6831-13-35

2. Hargreaves K, Abbott PV. Drugs for pain management in dentistry. Aust Dent J. 2005 Dec;50(4 Suppl 2):S14-22. https://doi.org/10.1111/j.1834-7819.2005.tb00378.x

3. Thornhill MH, Suda KJ, Durkin MJ, Lockhart PB. Is it time US dentistry ended its opioid dependence? J Am Dent Assoc. 2019 Oct;150(10):883-9. https://doi.org/10.1016/i.adaj.2019.07.003

4. Jayadev M, Karunakar P, Vishwanath B, Chinmayi SS, Siddhartha P, Chaitanya B. Knowledge and pattern of antibiotic and non narcotic analgesic prescription for pulpal and periapical pathologies: a survey among dentists. J Clin Diagn Res. 2014 Jul;8(7):ZC10-4. https://doi.org/10.7860/JCDR/2014/9645.4536

5. Haliti NR, Haliti FR, Koçani FK, Gashi AA, Mrasori SI, Hyseni VI, et al. Surveillance of antibiotic and analgesic use in the Oral Surgery Department of the University Dentistry Clinical Center of Kosovo. Ther Clin Risk Manag. 2015 Oct;11:1497-503. https://doi.org/10.2147/TCRM.S87595

6. Hollingworth SA, Chan R, Pham J, Shi S, Ford PJ. Prescribing patterns of analgesics and other medicines by dental practitioners in Australia from 2001 to 2012. Community Dent Oral Epidemiol. 2017 Aug;45(4):303-9. https://doi.org/10.1111/cdoe.12291

7. Halling F, Heymann P, Ziebart T, Neff A. Analgesic prescribing patterns of dental practitioners in Germany. J Craniomaxillofac Surg. 2018 Oct;46(10):1731-6. https://doi.org/10.1016/i.jcms.2018.07.005

8. Teoh L, Stewart K, Marino RJ, McCullough MJ. Part 2. Current prescribing trends of dental non-antibacterial medicines in Australia from 2013 to 2016. Aust Dent J. 2018 Apr;63(3):338-46. https://doi.org/10.1111/adj.12613

9. King NB, Fraser V. Untreated pain, narcotics regulation, and global health ideologies. PLoS Med. 2013;10(4):e1001411. https://doi.org/10.1371/journal.pmed.1001411

10. Álvares J, Guerra AA, Araújo VE, Almeida AM, Dias CZ, Ascef BO, et al. Access to medicines by patients of the primary health care in the Brazilian Unified Health System. Rev Saude Publica. 2017 Nov;51(2 suppl 2):20s. https://doi.org/10.11606/S1518-8787.2017051007139 
11. Lino PA, Sohn W, Singhal A, Martins MA, Silva ME, Abreu MH. A national study on the use of opioid analgesics in dentistry. Braz Oral Res. 2019 Aug;33:e076. https://doi.org/10.1590/1807-3107bor-2019.vol33.0076

12. Durán CE, Christiaens T, Acosta Á, Vander Stichele R. Systematic review of cross-national drug utilization studies in Latin America: methods and comparability. Pharmacoepidemiol Drug Saf. 2016 Jan;25(1):16-25. https://doi.org/10.1002/pds.3896

13. Minas Gerais. Secretaria de Estado da Saúde. Sistema Integrado de Gerenciamento da Assistência Farmacêutica - SiGAF. Belo Horizonte: Secretaria de Estado de Saúde; 2016 [cited 2020 Jan 3]. Available from: http://www.saude.mg.gov.br/component/gmg/page/352-sistema-integrado-de-gerenciamento-da-assitencia-farmaceutica-sigaf

14. Instituto Brasileiro de Geografia e Estatística - IBGE. Cidades. Rio de Janeiro: IBGE; 2017 [cited 2020 Apr 3]. Available from: https://cidades.ibge.gov.br/brasil/mg/panorama

15. Ministério da Saúde (BR). Datasus. Índice de Gini da renda domiciliar per capita segundo Município. Brasília, DF: Ministério da Saúde; 2010 [cited 2020 Jan 3]. Available from: http://tabnet.datasus.gov.br/cgi/ibge/censo/cnv/ginimg.def

16. Bolsa Família. Cadastro único. Brasília. DF: Ministério da Cidadania; 2017 [cited 2020 Apr 22]. Available from: https://aplicacoes.mds.gov.br/sagirmps/bolsafamilia/

17. World Health Organization - WHO. Collaborating Centre for Drug Statistics Methodology. Guidelines for ATC classification and DDD assignment 2019. Oslo: World Health Organization; 2018 [cited 2019 Jun]. Available from: https://www.whocc.no/filearchive/publications/2018_guidelines_web.pdf

18. Hutchinson JM, Patrick DM, Marra F, Ng H, Bowie WR, Heule L, et al. Measurement of antibiotic consumption: a practical guide to the use of the Anatomical Thgerapeutic Chemical classification and Definied Daily Dose system methodology in Canada. Can J Infect Dis. 2004 Jan;15(1):29-35. https://doi.org/10.1155/2004/389092

19. World Health Organization - WHO. Collaborating Centre for Drug Statistics Methodology. list of DDD combined products. Oslo: World Health Organization; 2019 [cited 2019 Jun]. Available from: https://www.whocc.no/ddd/list_of_DDD_combined_products/

20. Castro CG. Estudo de utilização de medicamentos: noções básicas. Rio de Janeiro: Fiocruz; 2000.

21. Instituto Brasileiro de Geografia e Estatística - IBGE. Estimativas da população residente no Brasil e unidades da federação com data de referência em $1^{\circ}$ de julho de 2016. Rio de Janeiro: IBGE; 2016 [cited 2020 Jan 3]. Available from: https://www.ibge.gov.br/estatisticas/sociais/populacao/9103-estimativas-de-populacao.htmle edicao=17283\&t=downloads

22. Programa das Nações Unidas para o Desenvolvimento. Atlas do desenvolvimento humano no Brasil. Brasília, DF: Atlas do Desenvolvimento Humano no Brasil; 2013 [cited 2020 Jan 3]. Available from: http://www.atlasbrasil.org.br/2013/

23. Instituto Brasileiro de Geografia e Estatística - IBGE. População residente em 2000 e população residente em 2010, por situação do domicílio, com indicação da população urbana residente na sede municipal. Rio de Janeiro: Instituto Brasileiro de Geografia e Estatística; 2016 [cited 2020 Jan 3]. Available from: https://censo2010.ibge.gov.br/sinopse/index. php?uf=31\&dados=29

24. Ministério da Saúde (BR). Datasus. Informações de Saúde - TABNET. Brasília, DF: Ministério da Saúde; 2010 [cited 2020 Jan 30 ]. Available from: http://www2.datasus.gov.br/DATASUS/index.php?area $=02$

25. Breiman L, Friedman J, Olshen RA, Stone CJ. Classification and regression trees. Boca Raton: CRC Press; 1998.

26. Costa CM, Silveira MR, Acurcio FA, Guerra AA, Guibu IA, Costa KS, et al. Use of medicines by patients of the primary health care of the Brazilian Unified Health System. Rev Saude Publica. 2017 Nov;51(2 suppl 2):18s. https://doi.org/10.11606/S1518-8787.2017051007144

27. Santos JS, Cruz AJ, Castilho LS, Abreu MH. Availability of analgesic and anti-inflammatory medicines in primary health care. Pesqui Bras Odontopediatria Clin Integr. 2020 Jan;20:e5236. https://doi.org/10.1590/pboci.2020.045

28. Rainsford KD. Ibuprofen: pharmacology, efficacy and safety. Inflammopharmacology. 2009 Dec;17(6):275-342. https://doi.org/10.1007/s10787-009-0016-x

29. Martins RC, Reis CM, Matta Machado AT, Amaral JH, Werneck MA, Abreu MH. Relationship between Primary and Secondary Dental Care in Public Health Services in Brazil. PLoS One. 2016 Oct;11(10):e0164986. https://doi.org/10.1371/journal.pone.0164986

30. Pucca GA Jr, Gabriel M, Araujo ME, Almeida FC. Ten years of a National Oral Health Policy in Brazil: innovation, boldness, and numerous challenges. J Dent Res. 2015 Oct;94(10):1333-7. https://doi.org/10.1177/0022034515599979

31. Esteves RS, Mambrini JV, Oliveira AC, Abreu MH. Performance of primary dental care services: an ecological study in a large Brazilian city. ScientificWorldJournal. 2013 Dec;2013:176589. https://doi.org/10.1155/2013/176589

32. Peres MA, Macpherson LM, Weyant RJ, Daly B, Venturelli R, Mathur MR, et al. Oral diseases: a global public health challenge. Lancet. 2019 Jul;394(10194):249-60. https://doi.org/10.1016/S0140-6736(19)31146-8

33. Shei A, Costa F, Reis MG, Ko Al. The impact of Brazil's Bolsa Família conditional cash transfer program on children's health care utilization and health outcomes. BMC Int Health Hum Rights. 2014 Apr;14(1):10. https://doi.org/10.1186/1472-698X-14-10

34. Calvasina P, O'Campo P, Pontes MM, Oliveira JB, Vieira-Meyer AP. The association of the Bolsa Familia Program with children's oral health in Brazil. BMC Public Health. 2018 Oct;18(1):1186. https://doi.org/10.1186/s12889-018-6084-3

35. Rocha S. O programa Bolsa Família: evolução e efeitos sobre a pobreza. Econ Soc. 2011 Apr;20(1):113-39. https://doi.org/10.1590/S0104-06182011000100005 
- Prescriptions of analgesics and anti-inflammatory drugs in municipalities from a Brazilian Southeast state

36. Agência Nacional de Vigilância Sanitária - Anvisa. Câmara de Regulação do Mercado de Medicamentos- CMED. Secretaria Executiva. Preços máximos de medicamentos por princípio ativo. Brasília, DF: Anvisa; 2020 [cited 2020 Apr 26].Available from: http://portal. anvisa.gov.br/documents/374947/5839648/LISTA_CONFORMIDADE_2020_04_vl.pdf/48b2fac3-225a-43d6-al18-13992cla8fcf

37. Anderson TJ, Saman DM, Lipsky MS, Lutfiyya MN. A cross-sectional study on health differences between rural and non-rural U.S. counties using the County Health Rankings. BMC Health Serv Res. 2015 Oct;15(1):441. https://doi.org/10.1186/s12913-015-1053-3

38. McCauley JL, Nelson JD, Gilbert GH, Gordan V, Durand SH, Mungia R, et al. Prescription drug abuse among patients in rural dental practices reported by members of the National Dental PBRN. J Rural Health. 2020 Mar;36(2):145-51. https://doi.org/10.1111/irh.12386 